\title{
Cattle Grazing and Yosemite Toad (Bufo canorus Camp) Breeding Habitat in Sierra Nevada Meadows
}

\author{
L. M. Roche, ${ }^{1}$ B. Allen-Diaz, ${ }^{2}$ D. J. Eastburn, ${ }^{3}$ and K. W. Tate ${ }^{4}$ \\ Authors are ${ }^{1}$ Postdoctoral Researcher, ${ }^{3}$ Research Associate, and ${ }^{4}$ Rangeland Watershed Specialist, Department of Plant Sciences, University of California, \\ Davis, CA 95616, USA; and ${ }^{2}$ Professor and Associate Vice President, University of California, Oakland, CA 94607, USA.
}

\begin{abstract}
Exclusion of cattle by fencing has been proposed to alleviate possible negative grazing impacts on hydrologic, water quality, and cover habitat conditions within Sierra Nevada meadows used by Yosemite toads (Bufo canorus Camp) for breeding. Our objectives were to: 1) determine associations between breeding pool habitat conditions and use of potential breeding pools by toads; and 2) determine how habitat conditions respond to cattle exclusion treatments on the Sierra National Forest, California. We randomly selected two toad occupied and two unoccupied breeding pools in each of nine meadows for this study $(n=36$ breeding pools). After baseline data collection in 2006, three meadow fencing treatments were implemented over the course of 3 yr. Treatments were fencing to exclude cattle from the entire meadow; fencing to exclude cattle from toad breeding and rearing areas, with grazing allowed in the remaining unfenced portion of the meadow; and cattle grazing allowed across entire meadow. We monitored hydrologic, water quality, and cover habitat variables as well as toad occupancy during the breeding seasons of 2006 through 2008. Concentrations of water quality constituents were uniformly low all years regardless of treatment. Occupied pools were shallower, warmer, and more nitrogen enriched than unoccupied breeding pools. We found no evidence of improved toad breeding pool habitat conditions following fencing compared to standard US Forest Service grazing management.
\end{abstract}

\section{Resumen}

La exclusión del ganado por medio de cercos ha sido propuesto para reducir los posibles impactos negativos del pastoreo en la calidad del agua, la hidrología y las condiciones de cobertura del hábitat dentro de las praderas de Sierra Nevada, usados por el sapo yosemite (Bufo canorus Camp) en su reproducción. Nuestros objetivos fueron: 1) Determinar las asociaciones entre las condiciones del hábitat en un estanque de cría y el uso de estanques potenciales de cría por sapos y 2) Determinar cómo las condiciones del hábitat responden a los tratamientos de exclusión del ganado en el bosque Nacional la Sierra en California. Seleccionamos al azar dos estanques de crianza de sapos ocupados y dos sin ocupar en cada una de las nueve praderas para este estudio ( $n=36$ estanques de cría). Después de los valores de referencia recabados en el 2006, se implantaron tres tratamientos de cercos en praderas por un periodo de tres años. Los tratamientos fueron, cercar para apartar el ganado de toda la pradera, cercar para excluir el ganado de la cría del sapo y su área de reproducción, permitiendo el pastoreo en la porción restante de la pradera sin cercar y permitir el pastoreo del ganado en toda la pradera. Se monitoreo la hidrología, calidad del agua y las variables de la cobertura del hábitat, así como la ocupación del sapo durante las temporadas de reproducción del 2006 al 2008. Monitoreamos las variables de hidrología, calidad de agua y la cobertura del hábitat así como la ocupación de los sapos durante las temporadas de reproducción del 2006 al 2008. Las concentraciones de los componentes en la calidad del agua fueron uniformemente bajos todos los años independientemente del tratamiento. Los estanques ocupados fueron menos profundos, más tibios y más ricos en nitrógeno que los estanques para reproducción vacios. No encontramos evidencia que mejoraran las condiciones del hábitat de los estanques de reproducción después del cercado de acuerdo a los parámetros del Servicio de Bosques de los Estados Unidos para manejo de pastizales.

Key Words: amphibian conservation, endangered species, mountain meadows, public lands, water quality

\section{INTRODUCTION}

Mountain meadows are critical habitat for native species, provide forage and water for grazing animals, and offer a distinct habitat contrast within the forest dominated Sierra Nevada mountain range (Ratliff 1985; Allen-Diaz 1991). Meadows comprise less than $10 \%$ of this landscape, but their

Research was funded by the US Department of Agriculture Forest Service, Pacific Southwest Region.

Correspondence: Leslie M. Roche, Dept of Plant Sciences, University of California, Mail Stop One, One Shields Ave, Davis, CA 95616, USA. Email: Imroche@ucdavis.edu

Manuscript received 23 May 2011; manuscript accepted 22 September 2011. ecological importance is substantial (Ratliff 1985; Kattleman and Embury 1996; Fites-Kaufman et al. 2007; Kuhn et al. 2011). Almost half of the 30 native amphibian species that depend on Sierra meadow habitat are considered at risk of extinction by state and federal regulatory agencies (Jennings and Hayes 1994; Jennings 1996). Yosemite toad (Bufo canorus Camp), one of the chief amphibian species of concern in the region, is endemic to the Sierra Nevada and has disappeared from much of its historic range (Jennings and Hayes 1994; Drost and Fellers 1996; Jennings 1996).

Yosemite toad is a California Species of Special Concern, a US Forest Service (USFS) Region 5 Sensitive Species, and a candidate species for federal listing under the Endangered 
Species Act (US Department of the Interior [USDI] 2002, 2004). This species utilizes high montane and subalpine wet meadows between $1900-\mathrm{m}$ and $3500-\mathrm{m}$ elevation for breeding and rearing habitat (Zeiner et al. 1988; Jennings and Hayes 1994; Jennings 1996). Yosemite toad declines have been attributed to cattle grazing, airborne chemical toxins, disease, and climatic shifts and variability (Davidson et al. 2002; USDI 2002). The USFS has specifically identified cattle grazing as an activity of concern for the conservation of sensitive and threatened wildlife species on National Forest lands in the Sierra Nevada (US Department of Agriculture [USDA] 2001). Extensive cattle grazing is common during summer months throughout much of the Yosemite toad's current range on USFS management areas.

Following annual onset of snow melt, Yosemite toads breed and lay eggs in shallow pools within high elevation wet meadows. These breeding pools are occupied by toads through the egg and tadpole life stages, which is approximately $6 \mathrm{wk}$ to 8 wk from May through August depending on annual weather conditions. After metamorphosis, the young of the year generally remain within the immediate rearing area until hibernation. Breeding pools are intermittent most summers, drying by late June to early August depending upon annual snowpack. Degradation of breeding pool hydrologic, water quality, and cover conditions are commonly proposed mechanisms by which cattle grazing may contribute to amphibian declines (Jennings and Hayes 1994; Jennings 1996; Healey et al. 1997; Jansen and Healey 2003; Knutson et al. 2004; Jofre et al. 2007; Burton et al. 2009). Excessive cattle fecal and urine deposition may increase nutrient levels in breeding pools, and hoof trampling could fragment and widen pools, leading to increased water temperature due to shallower depths. These shallow water depths could also increase bird predation on toads (Sherman and Morton 1984). Consumption of herbaceous cover by cattle could also increase predation and raise water temperatures. Although some anecdotal evidence exists, it is unclear which habitat characteristics drive breeding pool selection by Yosemite toads. It is also unclear if increased nutrient concentrations and temperatures, or reduced water depth, in breeding pools would be a benefit or disadvantage for developing tadpoles.

Various management actions have been proposed to reduce the potential for cattle grazing to degrade breeding pools (USDA 2001). In areas with toad occupied meadows, fencing of whole meadows and fencing of breeding areas within meadows are options being considered by the USFS, as is a shortened grazing period, which would result from deferring cattle turnout until postmetamorphosis (i.e., when toads enter the least potentially susceptible life stage). There is little published information to substantiate or refute concerns that standard USFS grazing practices are deteriorating breeding pool habitat conditions. Information is needed to identify key habitat conditions determining toad occupancy of breeding pools, and how meadow grazing management alternatives affect key habitat conditions.

Our study objectives were to: 1) determine relationships between potential breeding pool habitat conditions and pool selection for breeding by toads and 2) determine how breeding pool habitat conditions respond to fencing treatments to exclude cattle from whole meadows and breeding areas within meadows. Our specific hypothesis for objective 1 was that toads would select against potential breeding pools with: 1) relatively high nutrient concentrations, electrical conductivity, turbidity, and/or water temperatures and 2) relatively low vegetative cover and shallower water depths. Our specific hypothesis for objective 2 was that following treatment implementation, fenced treatments, relative to grazed treatments, would exhibit: 1) decreased nutrient concentrations, electrical conductivity, turbidity, and temperatures in breeding pool water and 2) increased vegetative cover and water depth in breeding pools. Toad responses (by lifestage and pool occupancy) to grazing and fencing treatments are reported in a companion study (Allen-Diaz et al. 2010; Lind et al. 2011).

\section{METHODS}

\section{Study Area}

This study was conducted on the High Sierra Ranger District, Sierra National Forest (SNF) on the western slope of the central Sierra Nevada. The landscape is a mosaic of meadows, massive rock outcrops, and coniferous forests dominated by Pinus contorta Loudon, Pinus jeffreyi Grev. \& Balf., Abies concolor (Gordon \& Glend.) Hildebr., and Abies magnifica A. Murray bis. Meadow habitats cover less than $10 \%$ of the landscape. Mean annual precipitation is $115 \mathrm{~cm}$ with $70 \%$ to $90 \%$ falling as snow from October to April. The region annually spends approximately $200 \mathrm{~d}$ under snowpack, and snowmelt occurs between May and June. Depending on annual snowpack and timing of snowmelt, Yosemite toads typically emerge from hibernation in late spring (May to June) to breed and lay eggs in shallow, flooded areas of meadows. As snowmelt progresses, broadly flooded habitat gradually recedes, resulting in limited inundation of depressional zones and complete desiccation of some ephemeral sites. Therefore, pool size is dynamic, ranging from large $\left(\sim 10 \mathrm{~m}^{2}\right)$ flooded areas at snow melt to smaller, discrete pools $\left(\sim 1 \mathrm{~m}^{2}\right)$ or swalelike habitats near dry down. Larvae metamorphose by mid to late summer, with toad metamorphs and subadults remaining within the breeding and rearing zone for the duration of the summer season (June through August; Karlstrom 1962; Sherman and Morton 1984).

Nine meadows were selected for this study, three meadows from each of three adjacent USFS cattle grazing allotments. All meadows: 1) had occupied and potentially occupied Yosemite toad breeding pools and 2) were subject to cattle grazing typical of USFS grazing lands in the region for at least a decade prior to the initiation of this study. The meadows were characterized by persistent shallow water tables (Table 1) and accumulations of mineral and organic materials. Meadow soils were classified as Mollisols and Inceptisols with Histosols found in the wettest areas of meadows. Meadow vegetation was characterized by a dense cover of graminoid and other herbaceous species, with peak production ranging from 1500 to $3400 \mathrm{~kg} \cdot \mathrm{ha}^{-1}$ (Table 1). Meadow areas with prolonged, shallow water tables were dominated by Carex utriculata Boott, Carex vesicaria L., and Carex simulata Mackenzie. Meadow areas with relatively deeper water tables were dominated by grasses and forbs such as Deschampsia caespitosa (L.) P. Beauv and Trifolium species. 
Table 1. Characteristics of nine meadows receiving cattle grazing (GRZ), toad breeding area fenced from cattle grazing (FBA), or whole meadow fenced from cattle grazing (FWM) treatments on the High Sierra Ranger District, Sierra National Forest, California. Values in parenthesis are 1 standard error of mean. Reported means are for 2006 through 2008.

\begin{tabular}{|c|c|c|c|c|c|c|c|}
\hline \multirow[b]{2}{*}{ Treatment } & \multirow[b]{2}{*}{ Meadow } & \multirow[b]{2}{*}{ Coordinates } & \multirow[b]{2}{*}{ Elevation (m) } & \multicolumn{2}{|c|}{ Meadow area (ha) } & \multirow[b]{2}{*}{ Water table ${ }^{1}(\mathrm{~cm})$} & \multirow[b]{2}{*}{$\operatorname{ANPP}^{2}\left(\mathrm{~kg} \cdot \mathrm{ha}^{-1}\right)$} \\
\hline & & & & Total & Fenced & & \\
\hline \multirow[t]{3}{*}{ GRZ } & 1 & lat $37^{\circ} 3^{\prime} 38^{\prime \prime} \mathrm{N}$, long $119^{\circ} 7^{\prime} 15^{\prime \prime} \mathrm{W}$ & 2130 & 1.8 & 0 & $35(1)$ & $3260(450)$ \\
\hline & 2 & lat $37^{\circ} 1^{\prime} 19^{\prime \prime} \mathrm{N}$, long $119^{\circ} 4^{\prime} 51^{\prime \prime} \mathrm{W}$ & 2120 & 2 & 0 & $18(2)$ & $3145(425)$ \\
\hline & 3 & lat $37^{\circ} 15^{\prime} 14^{\prime \prime} \mathrm{N}$, long $119^{\circ} 6^{\prime} 26^{\prime \prime} \mathrm{W}$ & 2605 & 1.6 & 0 & $14(5)$ & $1740(285)$ \\
\hline \multirow[t]{3}{*}{ FBA } & 4 & lat $37^{\circ} 15^{\prime} 56^{\prime \prime} \mathrm{N}$, long $119^{\circ} 6^{\prime} 34^{\prime \prime} \mathrm{W}$ & 2520 & 1.2 & 0.9 & $35(2)$ & $1680(50)$ \\
\hline & 5 & lat $37^{\circ} 1^{\prime} 43^{\prime \prime} \mathrm{N}$, long $119^{\circ} 5^{\prime} 21^{\prime \prime} \mathrm{W}$ & 2155 & 4 & 1.7 & $13(5)$ & $3435(305)$ \\
\hline & 6 & lat $37^{\circ} 4^{\prime} 24^{\prime \prime} \mathrm{N}$, long $119^{\circ} 6^{\prime} 44^{\prime \prime} \mathrm{W}$ & 2225 & 5.8 & 5.1 & $18(3)$ & $3395(240)$ \\
\hline \multirow[t]{3}{*}{ FWM } & 7 & lat $37^{\circ} 4^{\prime} 21^{\prime \prime} \mathrm{N}$, long $119^{\circ} 5^{\prime} 58^{\prime \prime} \mathrm{W}$ & 2270 & 1.2 & 1.2 & $8(4)$ & $2685(230)$ \\
\hline & 8 & lat $37^{\circ} 15^{\prime} 43^{\prime \prime} \mathrm{N}$, long $119^{\circ} 5^{\prime} 38^{\prime \prime} \mathrm{W}$ & 2660 & 3 & 3 & $5(2)$ & $1490(165)$ \\
\hline & 9 & lat $37^{\circ} 2^{\prime} 20^{\prime \prime} \mathrm{N}$, long $119^{\circ} 4^{\prime} 56^{\prime \prime} \mathrm{W}$ & 2260 & 0.7 & 0.7 & $13(4)$ & $2640(395)$ \\
\hline
\end{tabular}

${ }^{1}$ Mean depth to water table June through September measured at 10 wells located in each meadow (Mcllroy 2008).

${ }^{2}$ ANPP indicates aboveground net herbaceous primary productivity.

\section{Study Design and Meadow Fencing Treatments}

This study examined Yosemite toad breeding pool habitat condition response to three meadow fencing treatments implemented over $3 \mathrm{yr}$ in a randomized complete block design. In 2005, field surveys were conducted to identify cattle-grazed meadows with actively breeding Yosemite toad populations in each of three adjacent grazing allotments. Three meadows meeting these criteria were randomly selected within each allotment for inclusion in this study. Within each meadow, two potential Yosemite toad breeding pools determined to be occupied by toads, and two potential pools, which had characteristics similar to the groups of occupied pools, determined to be unoccupied during the 2005 meadow surveys were randomly selected (four pools per meadow, nine meadows, 36 pools total) from a larger set of surveyed pools. Toad breeding pool occupancy, hydrologic, water quality, and cover habitat data were collected for all 36 pools during the 2006 toad breeding season prior to cattle turnout and meadow fencing treatment implementation in July 2006. These same data were also collected during the 2007 and 2008 toad breeding season. The 2006 dataset served as baseline so that relative changes in habitat conditions among treatments could be determined over years of consecutive treatment implementation.

Each treatment was randomly allocated to one meadow in each allotment, so allotment was the blocking factor in this randomized complete block experimental design. Overall allotment management was consistent throughout the study with season-long continuous grazing. Grazing within the allotments occurred from late June/early July through September. The allotments ranged from 22000 ha to 27000 ha in area, and cattle numbers per allotment ranged from 200 to 250 cow-calf pairs. Meadow fencing treatments were: 1) fencing to completely exclude cattle from the whole meadow (fence whole meadow $[\mathrm{FWM}])$; 2) fencing to exclude cattle from the toad breeding area within the meadow, but grazing allowed in remainder of meadow (fence breeding area [FBA]); and 3) a nonfenced control, which was grazed in a manner consistent with allotment management prior to study initiation (grazed control [GRZ]). Area fenced for each meadow was based upon treatment received and spatial extent of toad breeding
(Table 1). Toad breeding areas were typically found in the wettest areas of the meadows. USFS grazing standards (GRZ treatment) for meadows are maximum levels of allowable annual utilization of meadow herbaceous vegetation. Prior to this study, the two fencing treatments were identified by the USFS Region 5 as potential conservation options for the Yosemite toad. The most restrictive option, FWM, was proposed to completely exclude cattle from meadow habitat so as to eliminate direct physical and depositional impacts. The FBA treatment was proposed as a less restrictive alternative measure. This treatment would reduce direct physical and deposition impacts at the breeding and rearing sites but had the potential risk of indirect chemical impacts via surface runoff from adjacent grazed areas.

During and $10 \mathrm{yr}$ prior to the study, maximum allowable annual herbaceous utilization on grazed meadows was $40 \%$ on a biomass basis. During the study period, annual herbaceous biomass utilization on the three standard grazing (GRZ treatment) meadows ranged from $15 \%$ to $43 \%, 31 \%$ to $54 \%$, and $9 \%$ to $43 \%$ in 2006,2007 , and 2008 , respectively. Cattle utilization of herbaceous vegetation in GRZ treatment meadows and herbaceous biomass production in all meadows were monitored via comparative yield at 10 paired plots per meadow (Interagency Technical Team [ITT] 1996; McIlroy 2008).

\section{Breeding Pool Habitat Data Collection}

Data on hydrologic, water quality, and cover habitat conditions were collected during 2006, 2007, and 2008 at all 36 study pools. Data collection was timed to represent each year's breeding and early rearing season when Yosemite toad adults were actively breeding in meadows and egg masses and tadpoles were present in occupied breeding pools. Two data collection events were conducted during the breeding and rearing season of each year $(2006=22$ May to 2 August; $2007=13$ May to 18 June; $2008=24$ May to 10 July). The first event was at the beginning of the breeding season when active breeding, pool selection, and egg laying was occurring. The second event was when tadpoles were in metamorphosis, preparing to enter their terrestrial phase. Pool occupancy by breeding Yosemite toads was determined on both sample 
events. A pool was categorized as occupied for the year if egg masses and/or tadpoles were observed in any number during either sample event of the year. A pool was categorized as unoccupied for the year if egg masses or tadpoles were absent during both sample events of the year.

Hydrologic data collected included characterization of pool flow regime and water depth. At the first sample event each year, each breeding pool was categorized as flowing (lotic) or nonflowing (lentic) based upon direct observation of flow conditions. Mean pool water depth was determined from 20 water depth measurements taken along two permanent transects across each pool during the early sample event, with mean depth calculated from the transect readings. Percent total herbaceous vegetative cover for each pool was determined from 20 point intercept readings taken along transects across each pool. Water quality data collected included physical and chemical characteristics. A composite water sample was collected from each pool during the first sample event. The composite sample was composed of subsamples collected along the two sample transects crossing each pool, integrating spatial variation in water quality conditions across each pool. During the second sample event, the majority of pools were too shallow to collect water samples without sample contamination by suspension of pool bottom detritus and sediments.

Total nitrogen (TN) and total phosphorus (TP) concentrations (ppm) were determined on nonfiltered subsamples following Yu et al. (1994) and standard method SM4500-P.D (Eaton et al. 2005), respectively. Nephelometric turbidity units (ntu), conductivity $\left(\mathrm{dS} \cdot \mathrm{dm}^{-1}\right)$ and $\mathrm{pH}$ were determined on nonfiltered subsamples via standard methods SM2130, SM2510, and SM4500- $\mathrm{H}^{+}$, respectively (Eaton et al. 2005). Ammonium-nitrogen $\left(\mathrm{NH}_{4}-\mathrm{N}\right)$, nitrate-nitrogen $\left(\mathrm{NO}_{3}-\mathrm{N}\right)$, soluble reactive phosphorus $\left(\mathrm{PO}_{4}-\mathrm{P}\right)$, and dissolved organic carbon (DOC) concentrations (ppm) were determined on filtered $(0.45 \mu \mathrm{m})$ subsamples following Doane and Horwath (2003; Verdouw et al. 1978), standard method SM4500D (Eaton et al. 2005), and standard method SM5310C (Eaton et al. 2005), respectively. Minimum detection limits were $0.01 \mathrm{ppm}$ for $\mathrm{TN}, \mathrm{NH}_{4}-\mathrm{N}$, and $\mathrm{NO}_{3}-\mathrm{N} ; 0.005 \mathrm{ppm}$ for TP and $\mathrm{PO}_{4}-\mathrm{P} ; 0.1 \mathrm{ppm}$ for DOC; $1.0 \mathrm{ntu}$ for turbidity; and $0.1 \mathrm{dS} \cdot \mathrm{dm}^{-1}$ for conductivity.

During the first sample visit an automatic recording temperature meter was deployed in each pool and retrieved during the second sample visit. Water temperature in each pool was recorded continuously every $0.5 \mathrm{~h}$ throughout the breeding and early rearing season each year. A temperature meter was deployed in each meadow to measure air temperature, a covariate necessary for analysis of water temperature data (Tate et al. 2007). Daily minimum, mean, and maximum breeding pool water and air temperatures were calculated.

\section{Data Analysis}

The data were longitudinal due to repeated measurements on the experimental units (36 Yosemite toad breeding pools) over 3 yr (2006, 2007, and 2008). The data were also hierarchically structured with breeding pool nested within meadow and meadow nested within allotment. We used linear mixed model (LMM) and generalized linear mixed model (GLMM) regression analyses to correlate breeding pool habitat conditions to toad occupancy (objective 1) and to test pool habitat condition response to meadow fencing treatments (objective 2; Pinheiro and Bates 2000; RabeHesketh and Skrondal 2008). LMMs were used for temperature and $\mathrm{pH}$, which were normally distributed with homogeneous variance (Pinheiro and Bates 2000). GLMMs were used for count responses (turbidity, electrical conductivity [EC], $\mathrm{NO}_{3}-\mathrm{N}, \mathrm{NH}_{4}-\mathrm{N}, \mathrm{TN}, \mathrm{TP}$, water depth, and vegetative cover) using the Poisson probability distribution function with robust standard errors for overdispersion (Rabe-Hesketh and Skrondal 2008). In all mixed models, we specified pool identity, meadow identity, and allotment identity as serial random effects to account for repeated measurements on pools and hierarchical nesting. Significance of fixed effects was determined based on Wald tests, and fixed effect coefficients were estimated using restricted maximum likelihood (LMMs) or adaptive quadrature (GLMMs). Analysis was conducted with the statistical software package Stata/SE 11.1 (StataCorp 2007). For objective 1 , the significance of relationships between breeding pool habitat variables and toad occupancy was determined via bivariate analyses with toad occupancy rate $(0 \mathrm{yr}$, 1 to $3 \mathrm{yr}$, and $4 \mathrm{yr}$ ) as the fixed independent effect and each habitat variable as the dependent variable. GLMMs and LMMs for objective 2 analysis included year (2006, 2007, and 2008), treatment (GRZ, FBA, and FWM), and year by treatment interaction as fixed effects. In accordance with the experimental design, the hypothesis for objective 2 was evaluated via the significance of the year by treatment interaction and relative pattern of response to treatment over time. The remaining fixed variables account for inherent differences between treatment groups at the outset of the study (i.e., treatment variable) and annual variation (i.e., year variable). Pool flow condition (lentic, lotic) was included as a fixed effect covariate based on correlations revealed in analysis for objective 1 . For water temperature response variables (daily minimum, mean, maximum), Julian day and air temperature were also included as fixed effect covariates.

\section{RESULTS}

\section{Toad Occupancy Rates and Habitat Conditions}

During the study period, annual precipitation ranged from $59 \%$ to $127 \%$ of average, and annual number of occupied breeding pools was positively correlated (Spearman's rho $=1.0$, $P<0.0001$ ) with annual precipitation (Table 2). Yosemite toad occupancy rates of potential breeding pools was significantly $(P<0.05)$ associated with water depth, daily mean and maximum water temperatures, and TN (Fig. 1). Breeding pools occupied 1 or more years were on average $1.8 \mathrm{~cm}$ shallower than pools never occupied by toads. Daily mean and maximum water temperatures averaged $1.9^{\circ} \mathrm{C}$ and $4.3^{\circ} \mathrm{C}$ warmer, respectively, in pools occupied 1 or more years compared to pools never occupied. There was no significant difference in water depth or temperature for pools occupied 1 to $3 \mathrm{yr}$ compared to pools occupied all $4 \mathrm{yr}$ of observation $(P>0.10$ in all cases). Breeding pools occupied $4 \mathrm{yr}$ had significantly higher TN concentrations than pools occupied 0 or 1 to $3 \mathrm{yr}$. TN 
Table 2. Annual Yosemite toad occupancy of breeding pools, percent of average annual precipitation, and mean date of pool drying for 36 breeding pools located across nine meadows on the High Sierra Ranger District, Sierra National Forest, California.

\begin{tabular}{ccccccc}
\hline & \multicolumn{3}{c}{ Number of pools } & & \\
Year & Occupied & Occupied and lentic & Occupied and lotic & \% Pools lentic & \% Average precipitation & Mean dry date \\
\hline 2006 & 14 & 7 & 7 & 61 & 127 & August 2 \\
2007 & 8 & 8 & 0 & 72 & 59 & June 18 \\
2008 & 11 & 5 & 6 & 57 & 73 & July 10 \\
\hline
\end{tabular}

concentrations were not statistically different between pools occupied 0 and pools occupied 1 to 3 yr (Fig. 1). Pool water turbidity, $\mathrm{EC}, \mathrm{DOC}, \mathrm{NO}_{3}-\mathrm{N}, \mathrm{NH}_{4}-\mathrm{N}, \mathrm{TP}, \mathrm{pH}$, and herbaceous cover were not significantly related to toad occupancy rate $(P>0.10$ in all cases $)$.

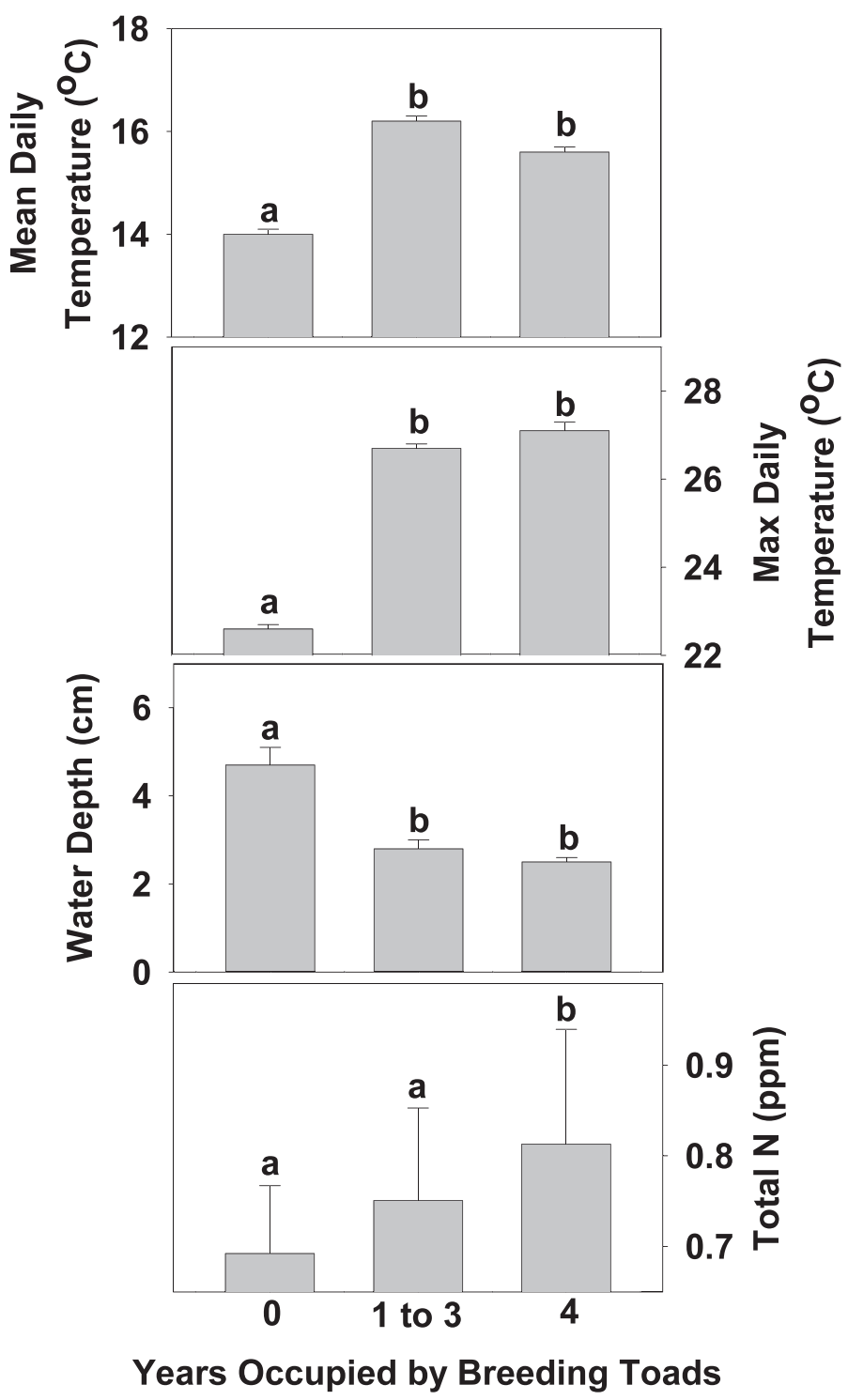

Figure 1. Mean values for habitat metrics, which were significantly different $(P<0.05)$ among Yosemite toad breeding pools occupied 0 of $4 \mathrm{yr}, 1$ to 3 of $4 \mathrm{yr}$, and 4 of $4 \mathrm{yr}$ during the period 2005 through 2008. Data were collected from 36 breeding pools located across nine meadows on the High Sierra Ranger District, Sierra National Forest, California. Bars are 1 standard error of mean.
Occupancy was evenly split between lentic (nonflowing) and lotic (flowing) pools in 2006 and 2008. However, only lentic pools were occupied during the dry, short breeding season of 2007 when the majority of pools were lentic (Table 2). Of the eight pools consistently occupied 2006 through 2008, three had lentic flow every year and three were lentic for 2 of $3 \mathrm{yr}$. Two of the eight pools consistently occupied had lotic conditions for 2 of $3 \mathrm{yr}$ (2006 and 2008). Flow regime was a significant $(P<0.05)$ determinant of pool water depth and temperature, as well as of DOC, TN, TP, pH, and turbidity (Fig. 2). Lentic potential breeding pools were on average shallower and warmer than lotic potential breeding pools. Lentic pools had higher levels of DOC, TN, TP, and turbidity than lotic pools. Lentic pools were more acidic than lotic pools (Fig. 2).

\section{Pool Habitat Response to Meadow Fencing}

Overall, concentrations for water quality constituents were uniformly low with a narrow range observed for all variables (Tables 3 and 4). Over $80 \%$ of water samples had concentrations below detection limits for $\mathrm{NO}_{3}-\mathrm{N}(0.01 \mathrm{ppm})$ and $\mathrm{PO}_{4}-\mathrm{P}$ (0.005 ppm) each year. In $2008,22 \%$ of samples were below detection for $\mathrm{NH}_{4}-\mathrm{N}(0.01 \mathrm{ppm})$ and $17 \%$ were below detection for TP (0.005 ppm; Table 4). Mean concentrations of $\mathrm{NH}_{4}-\mathrm{N}, \mathrm{PO}_{4}-\mathrm{P}, \mathrm{TN}$, and TP were lower in 2008 compared to 2006 and 2007 for all treatments.

There was no significant treatment by year interaction (i.e., treatment effect) for turbidity, $\mathrm{pH}, \mathrm{EC}$, herbaceous cover, water depth, $\mathrm{NO}_{3}-\mathrm{N}$, or TN (Tables 3 and 4). With the exception of herbaceous cover, these variables did vary significantly from year to year (i.e., year effects). Analysis revealed a statistically significant treatment by year interaction for $\mathrm{NH}_{4}-\mathrm{N}, \mathrm{PO}_{4}-\mathrm{P}, \mathrm{TP}$, and pool water temperature; however, there was no clear pattern of response to the treatments over the study period (Fig. 3).

\section{DISCUSSION}

We found no evidence of improved toad breeding pool habitat conditions following fencing compared to standard USFS grazing management. These results are consistent with the findings in a companion study, which reported no detectable effects of the grazing treatments on either tadpole, young of the year, or pool occupancy responses (Allen-Diaz et al. 2010; Lind et al. 2011). An unexpected and important finding of this study was that, for this system, concentrations of water quality constituents generally of ecological and biological concern were uniformly low in 2006 when all meadows had been grazed for at least a decade, and remained low throughout the study regardless of treatment. Excessive nitrogen and phosphorus 


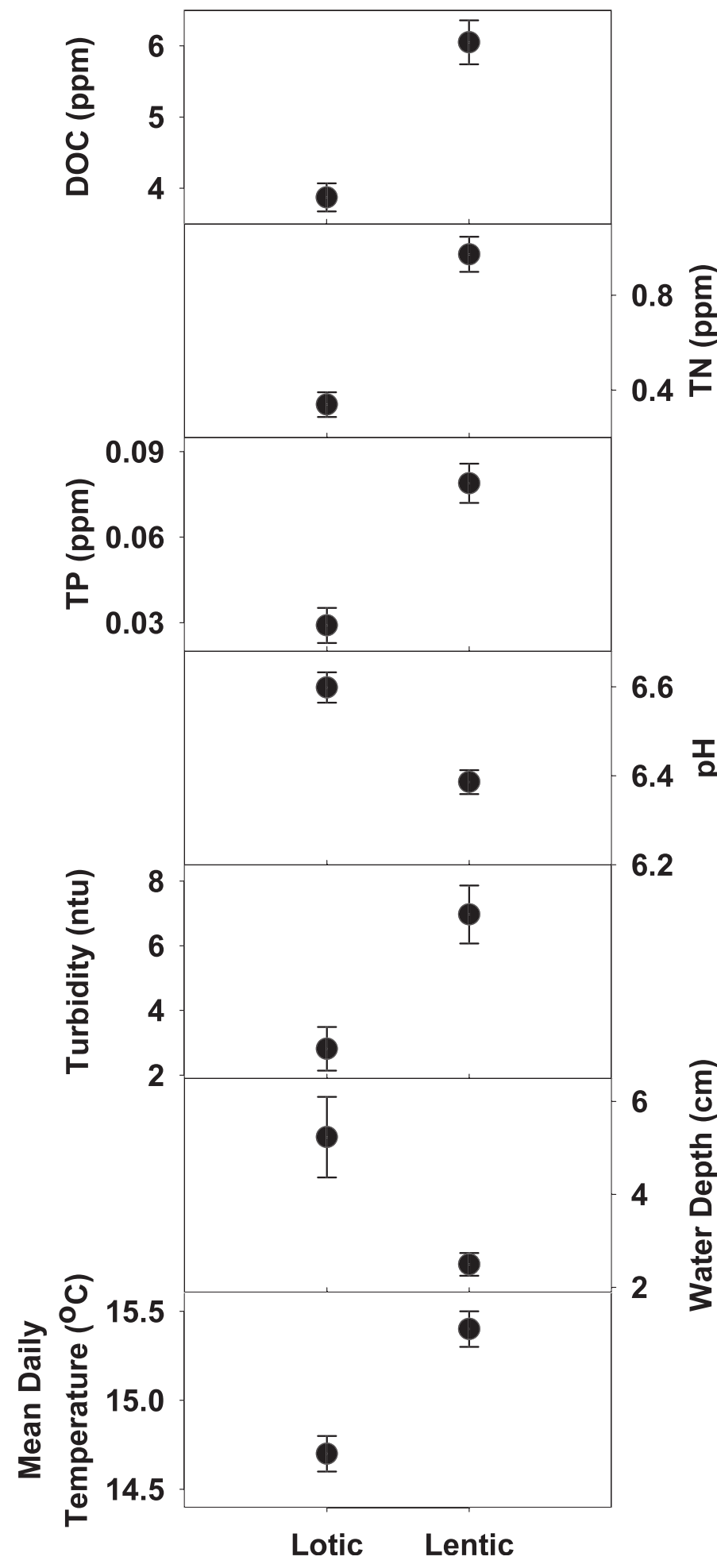

Figure 2. Mean values for habitat metrics, which were significantly different $(P<0.05)$ among Yosemite toad breeding pools with lotic compared to lentic flow conditions. Data were collected from 36 breeding pools located on nine meadows across the High Sierra Ranger District, Sierra National Forest, California. Bars are 1 standard error of mean.

loading by cattle has been cited as a possible contributor to aquatic species declines via both direct lethal and sublethal developmental effects (Rouse et al. 1999; Knutson et al. 2004; Schmutzer et al. 2008). Previous work has shown significant differences in sensitivity to nutrient levels among larvae of different amphibian species (Marco et al. 1999); however, some anurans are apparently not as sensitive to increased nutrient levels compared to fish species (Jofre and Karasov 1999). Marco et al. (1999) reported that the Oregon spotted frog (Rana pretiosa Baird \& Girard) was the most sensitive anuran tested, showing significant mortality after $15 \mathrm{~d}$ of exposure to $\mathrm{NO}_{3}-\mathrm{N}$ greater than $12.5 \mathrm{ppm}$. Western toad (Bufo boreas Baird \& Girard), a close relative of the Yosemite toad, was the least sensitive amphibian, showing no response after $15 \mathrm{~d}$ of treatments greater than $20 \mathrm{ppm} \mathrm{NO}_{3}-\mathrm{N}$. In this extensively grazed system (see Methods for description), we found no evidence of nitrogen or phosphorus concentrations approaching levels of concern, regardless of treatment or year. Nitrogen and phosphorus concentrations in natural water bodies (i.e., streams, lakes, and rivers) in the region are generally of concern when $\mathrm{NO}_{3}-\mathrm{N}, \mathrm{PO}_{4}-\mathrm{P}$, and TP concentrations exceed $0.30,0.05$, and $0.1 \mathrm{ppm}$, respectively (MacDonald et al. 1991). Mean concentrations observed in breeding pools during the study were $<0.01,0.008$, and $0.06 \mathrm{ppm}$ for $\mathrm{NO}_{3}-\mathrm{N}, \mathrm{PO}_{4}-\mathrm{P}$, and TP. Observed concentrations were an order of magnitude below levels of ecological concern. Over $80 \%$ of $\mathrm{NO}_{3}-\mathrm{N}$ and $\mathrm{PO}_{4}-\mathrm{P}$ observations were below 0.01 and

$0.005 \mathrm{ppm}$, respectively. Observed $\mathrm{NH}_{4}-\mathrm{N}$ concentrations were not of ecological concern. Ammonia $\left(\mathrm{NH}_{3}\right)$ concentrations greater than $0.6 \mathrm{ppm}$ (ammonia-nitrogen $\left[\mathrm{NH}_{3}-\mathrm{N}\right]$ concentrations of $0.49 \mathrm{ppm}$ ) have been shown to be of biological concern for some sensitive anuran species (Jofre and Karasov 1999). In water, ammonium and ammonia exist in equilibrium, and the ratio of ammonia to ammonium in situ is dependent upon environmental conditions. The un-ionized $\mathrm{NH}_{3}-\mathrm{N}$ concentrations can be calculated based on measured temperature and $\mathrm{pH}$ values. Under mean observed $\mathrm{pH}$, temperature, and $\mathrm{NH}_{4}-\mathrm{N}$ levels (Tables 3 and 4), mean $\mathrm{NH}_{3}-\mathrm{N}$ concentration would have been $<0.001 \mathrm{ppm}$ in situ. At maximum observed $\mathrm{NH}_{4}-\mathrm{N}$ concentration of $0.775 \mathrm{ppm}$, $\mathrm{NH}_{3}-\mathrm{N}$ concentration in situ would have been $<0.002 \mathrm{ppm}$. Excessive nutrient loading to breeding pools does not appear to be a concern in this system under standard USFS grazing management.

We hypothesized that toads would select against breeding pools with relatively high nutrient concentrations, turbidity, and temperature and against pools with relatively low cover and shallower water depths. Only water depth, temperature, and TN were significant predictors of toad occupancy of potential breeding pools over the $3 \mathrm{yr}$ of study (Fig. 1). Toad occupancy rate increased with water temperature and $\mathrm{TN}$ concentration, and decreased with water depth, leading us to reject our hypothesis. Lentic pools had warm, shallow water with greater TN levels relative to lotic pools (Fig. 2). Yet, toads only preferentially selected for lentic pools in 2007. Annual precipitation was $59 \%$ of normal, and $72 \%$ of all potential breeding pools were lentic (Table 2). This suggests that, over time, lentic pools may provide more consistent and dependable breeding habitat, but the primary habitat variables driving occupancy appear to be water temperature, depth, and TN. Although this is the first work to systematically examine toad habitat conditions, anecdotal evidence has previously suggested that toads prefer to breed in shallow pools and slow moving ephemeral streams (Sherman and Morton 1984). 
Table 3. Mean values of water quality and cover habitat variables for Yosemite toad breeding pools in nine meadows (three per treatment) treated with ambient cattle grazing (GRZ), toad breeding area fenced from cattle grazing (FBA), and whole meadow fenced from cattle grazing (FWM). Data were collected from 36 breeding pools (four per meadow) located on the High Sierra Ranger District, Sierra National Forest, California. Values in parenthesis are 1 standard error of mean. Lower portion of table displays results of mixed effects regressions to determine statistical significance of year, treatment, and year by treatment interaction. Treatment effect was evaluated via significance of the year by treatment interactions and relative pattern of response to treatments over time. Main effects account for inherent differences between treatment groups and annual variation.

\begin{tabular}{|c|c|c|c|c|c|c|c|c|c|c|}
\hline \multirow[b]{2}{*}{ Year } & \multirow[b]{2}{*}{ Treatment } & \multirow{2}{*}{$\begin{array}{c}\text { Turbidity } \\
\text { (nephelometric } \\
\text { turbidity units } \\
\text { [NTU]) } \\
\end{array}$} & \multirow[b]{2}{*}{$\mathrm{pH}$} & \multirow{2}{*}{$\begin{array}{c}\text { Electrical } \\
\text { conductivity } \\
\text { (EC) (dS/dm) }\end{array}$} & \multirow[b]{2}{*}{$\mathrm{DOC}^{1}(\mathrm{ppm})$} & \multirow{2}{*}{$\begin{array}{l}\text { Herbaceous } \\
\text { cover } \\
(\%)\end{array}$} & \multicolumn{3}{|c|}{ Daily water temperature $\left({ }^{\circ} \mathrm{C}\right)$} & \multirow{2}{*}{$\begin{array}{l}\text { Water depth } \\
\quad(\mathrm{cm})\end{array}$} \\
\hline & & & & & & & Minimum & Mean & Maximum & \\
\hline \multirow[t]{3}{*}{2006} & GRZ & $4.6(1.2)$ & $6.4(0.03)$ & $15.2(0.8)$ & $5.3(0.4)$ & $56(7)$ & $7.6(0.2)$ & $14.2(0.2)$ & $24.2(0.2)$ & $6.5(2.0)$ \\
\hline & FBA & $4.3(1.5)$ & $6.4(0.04)$ & $14.3(1.2)$ & $4.5(0.2)$ & $76(7)$ & $9.1(0.2)$ & $15.7(0.2)$ & $25.0(0.3)$ & $2.5(0.3)$ \\
\hline & FWM & $9.9(2.2)$ & $6.4(0.03)$ & $18.5(1.0)$ & $6.0(0.3)$ & $75(6)$ & $9.9(0.2)$ & $16.9(0.2)$ & $27.3(0.3)$ & $2.9(0.5)$ \\
\hline \multirow[t]{3}{*}{2007} & GRZ & $2.9(0.7)$ & $6.3(0.07)$ & $18.4(1.8)$ & $6.5(0.8)$ & $61(7)$ & $7.6(0.1)$ & $13.1(0.1)$ & $21.7(0.3)$ & $4.0(1.2)$ \\
\hline & FBA & $3.9(1.0)$ & $6.1(0.08)$ & $16.0(2.3)$ & $6.2(0.9)$ & $80(6)$ & $8.5(0.1)$ & $14.9(0.1)$ & $24.4(0.3)$ & $1.4(0.3)$ \\
\hline & FWM & $5.7(1.6)$ & $6.2(0.03)$ & $19.0(2.2)$ & $9.2(0.6)$ & $66(9)$ & $9.6(0.2)$ & $16.3(0.1)$ & $25.8(0.2)$ & $2.0(0.5)$ \\
\hline \multirow[t]{3}{*}{2008} & GRZ & $2.4(0.8)$ & $6.8(0.10)$ & $16.0(1.2)$ & $8.2(1.2)$ & $65(6)$ & $7.9(0.1)$ & $14.3(0.2)$ & $24.7(0.3)$ & $5.6(1.5)$ \\
\hline & FBA & $3.5(1.1)$ & $6.6(0.06)$ & $13.7(2.3)$ & $6.8(0.7)$ & $75(4)$ & $7.9(0.2)$ & $15.3(0.2)$ & $25.7(0.3)$ & $2.1(0.4)$ \\
\hline & FWM & $6.7(1.8)$ & $6.7(0.06)$ & $16.7(1.1)$ & $8.4(1.0)$ & $69(6)$ & $8.6(0.2)$ & $16.0(0.2)$ & $26.5(0.2)$ & $2.9(0.5)$ \\
\hline Year & & $P<0.05$ & $P<0.05$ & $P<0.05$ & $P<0.05$ & ns & $P<0.05$ & $P<0.05$ & $P<0.05$ & $P<0.05$ \\
\hline Treatment & & $P<0.05$ & ns & ns & ns & $P<0.05$ & ns & $P<0.10$ & $P<0.10$ & $P<0.05$ \\
\hline Year $\times$ Treatment & & ns & ns & ns & ns & ns & $P<0.05$ & $P<0.05$ & $P<0.05$ & ns \\
\hline
\end{tabular}

${ }^{1}$ DOC indicates dissolved organic carbon; ns, not significant.

Habitat surveys on the eastern Sierra slope in Mono County, California, have also demonstrated that Yosemite toads preferentially select wet meadow bottoms, which generally provide persistent breeding and rearing pools (Morton and Pereyra 2010).

Yosemite toad breeding pool habitat conditions did not significantly change following three consecutive years of fencing to exclude cattle. In response to consecutive years of fencing treatment application, we expected to see trends toward improved water quality (i.e., lower constituent concentrations), increased herbaceous cover, and increased water depth in fenced pools relative to pools in grazed meadows. We found no support for this hypothesis for turbidity, $\mathrm{pH}, \mathrm{EC}$, herbaceous cover, water depth, $\mathrm{NO}_{3}-\mathrm{N}$, or TN. Statistical analysis did detect annual variation among treatment means for $\mathrm{NH}_{4}-\mathrm{N}, \mathrm{PO}_{4}-\mathrm{P}, \mathrm{TP}$, and water temper-

Table 4. Mean values of water quality habitat variables for Yosemite toad breeding pools in nine meadows (three per treatment) treated with ambient cattle grazing (GRZ), toad breeding area fenced from cattle grazing (FBA), and whole meadow fenced from cattle grazing (FWM). Data were collected from 36 breeding pools (four per meadow) located on the High Sierra Ranger District, Sierra National Forest, California. Values in parenthesis are 1 standard error of mean. Lower portion of table displays results for mixed effects regressions to determine significance of year, treatment, and year by treatment interaction. Treatment effect was evaluated via significance of year by treatment interactions and relative pattern of response to treatments over time. Main effects account for inherent differences between treatment groups and annual variation.

\begin{tabular}{|c|c|c|c|c|c|c|c|c|c|c|c|}
\hline \multirow[b]{2}{*}{ Year } & \multirow[b]{2}{*}{ Treatment } & \multicolumn{2}{|c|}{$\mathrm{NO}_{3}-\mathrm{N}^{1}$} & \multicolumn{2}{|c|}{$\mathrm{NH}_{4}-\mathrm{N}^{1}$} & \multicolumn{2}{|c|}{$\mathrm{PO}_{4}-\mathrm{P}^{2}$} & \multicolumn{2}{|c|}{ Total $P^{2}$} & \multicolumn{2}{|c|}{ Total $\mathrm{N}^{2}$} \\
\hline & & ppm & $\%<\mathrm{DL}^{3}$ & ppm & $\%<\mathrm{DL}$ & ppm & $\%<\mathrm{DL}$ & ppm & $\%<\mathrm{DL}$ & ppm & $\%<\mathrm{DL}$ \\
\hline \multirow[t]{3}{*}{2006} & GRZ & $0.008(0.001)$ & 71 & $0.15(0.03)$ & 0 & $0.010(0.003)$ & 76 & $0.05(0.01)$ & 3 & $0.6(0.1)$ & 0 \\
\hline & FBA & $0.007(0.001)$ & 86 & $0.18(0.03)$ & 0 & $0.007(0.002)$ & 77 & $0.06(0.01)$ & 9 & $0.7(0.1)$ & 0 \\
\hline & FWM & $0.013(0.003)$ & 53 & $0.23(0.03)$ & 0 & $0.009(0.002)$ & 74 & $0.08(0.01)$ & 3 & $0.9(0.1)$ & 0 \\
\hline \multirow[t]{3}{*}{2007} & GRZ & $0.009(0.004)$ & 83 & $0.16(0.04)$ & 8 & $0.010(0.005)$ & 67 & $0.07(0.02)$ & 0 & $1.0(0.3)$ & 0 \\
\hline & FBA & $0.006(0.001)$ & 91 & $0.15(0.03)$ & 0 & $0.004(0.001)$ & 91 & $0.09(0.02)$ & 0 & $1.1(0.2)$ & 0 \\
\hline & FWM & $0.006(0.001)$ & 80 & $0.23(0.05)$ & 0 & $0.010(0.005)$ & 80 & $0.11(0.03)$ & 0 & $1.5(0.3)$ & 0 \\
\hline \multirow[t]{3}{*}{2008} & GRZ & $0.006(0.001)$ & 92 & $0.02(0.01)$ & 33 & $0.004(0.001)$ & 92 & $0.02(0.01)$ & 25 & $0.4(0.1)$ & 0 \\
\hline & FBA & $0.006(0.001)$ & 91 & $0.03(0.01)$ & 18 & $0.005(0.002)$ & 91 & $0.03(0.01)$ & 18 & $0.4(0.1)$ & 0 \\
\hline & FWM & $0.016(0.010)$ & 83 & $0.06(0.02)$ & 17 & $0.006(0.002)$ & 75 & $0.04(0.01)$ & 8 & $0.4(0.1)$ & 0 \\
\hline Year & & $P<0.05$ & - & $P<0.05$ & - & $P<0.05$ & - & $P<0.05$ & - & $P<0.05$ & - \\
\hline Treatment & & $P<0.05$ & - & $P<0.05$ & - & $P<0.05$ & - & $P<0.05$ & - & $P<0.05$ & - \\
\hline Year $\times$ Treatment & & $\mathrm{ns}^{4}$ & - & $P<0.05$ & - & $P<0.05$ & - & $P<0.05$ & - & ns & - \\
\hline
\end{tabular}

${ }^{1}$ Concentrations below total $\mathrm{N}, \mathrm{NO}_{3}-\mathrm{N}$, and $\mathrm{NH}_{4}-\mathrm{N}$ detection level were set to $0.005 \mathrm{ppm}$, which is one-half the detection level for this analysis (0.01 ppm).

${ }^{2}$ Concentrations below total $\mathrm{P}$ and $\mathrm{PO}_{4}-\mathrm{P}$ detection level were set to $0.0025 \mathrm{ppm}$, which is one-half the detection level for this analysis (0.005 ppm).

${ }^{3}$ Percent of samples below detection limit.

${ }^{4}$ ns indicates not significant. 

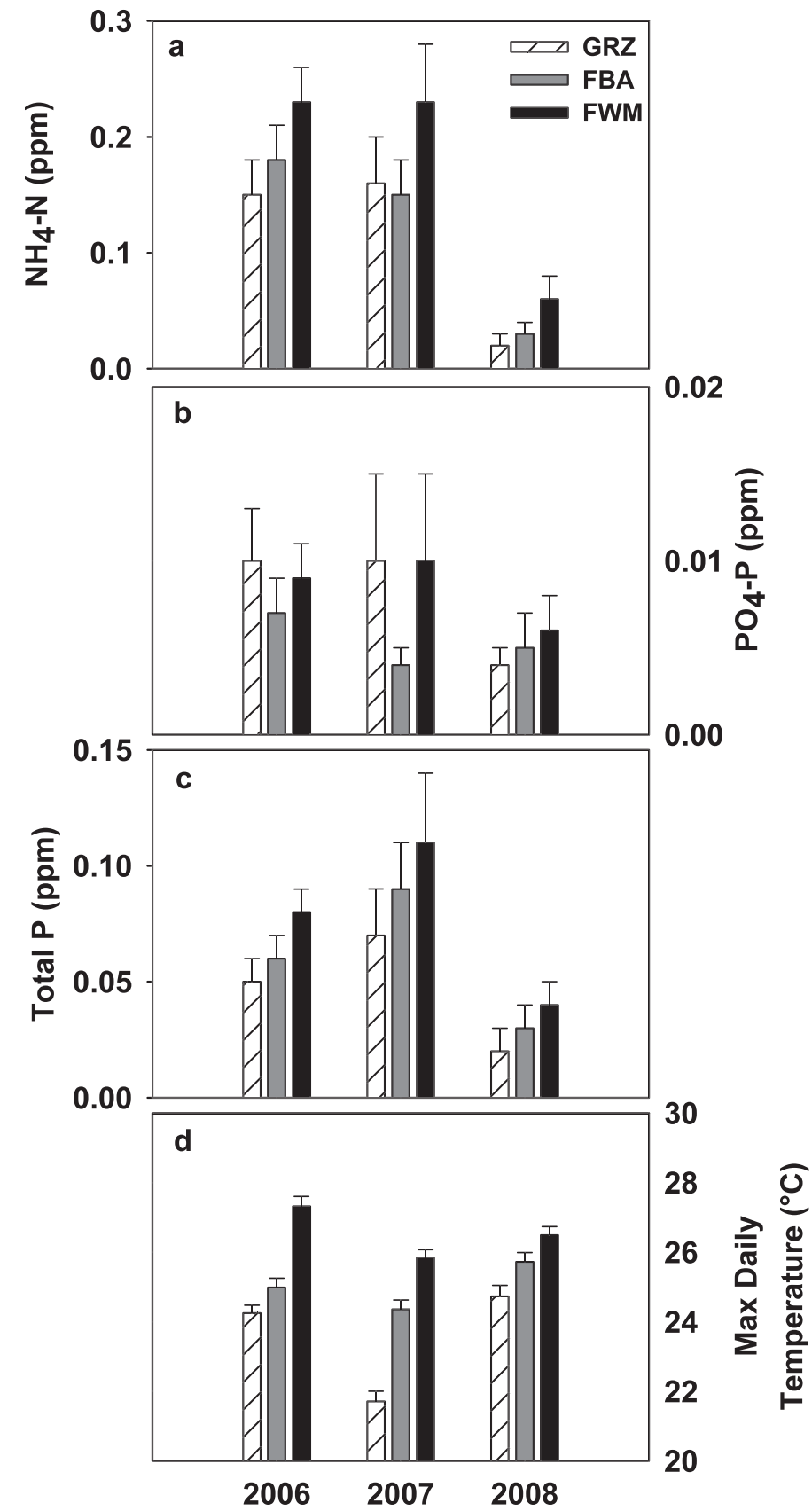

Figure 3. Mean (a) ammonium $\left(\mathrm{NH}_{4}-\mathrm{N}\right)$, (b) soluble reactive phosphorus $\left(\mathrm{PO}_{4}-\mathrm{P}\right),(\mathbf{c})$ total phosphorus (total $\left.\mathrm{P}\right)$, and (d) maximum daily water temperature for Yosemite toad breeding pools treated with ambient cattle grazing (GRZ), toad breeding area fenced from cattle grazing (FBA), or entire meadow fenced from cattle grazing (FWM). Data were collected from 36 breeding pools located on nine meadows across the High Sierra Ranger District, Sierra National Forest, California.

ature (daily minimum, mean, and maximum) in the form of a significant year by treatment interaction. This year by treatment interaction could: 1) indicate a pattern of habitat response to treatment application over years (the study hypothesis) or 2) reflect annual variation among treatments over years due to environmental variables or random variation. The expected trend following cattle exclusion treatments (FBA, FWM) was for nutrient concentrations and temperature to decrease in comparison to standard grazing (GRZ). The year to year variation observed among treatment means does not support this hypothesis (Fig. 3). For example, the year by treatment interaction for $\mathrm{NH}_{4}-\mathrm{N}$ was driven by the reduction of FBA treatment concentrations in 2007 relative to the other treatments in 2006 and 2008 (Fig. 3a). $\mathrm{PO}_{4}-\mathrm{P}$ concentrations increased, rather than decreased, in fenced treatments relative to the grazed meadows from 2006 to 2008 (Fig. 3b). Over $80 \%$ of samples were below detection limit for $\mathrm{PO}_{4}-\mathrm{P}$, so caution must be used when interpreting $\mathrm{PO}_{4}-\mathrm{P}$ response to treatment. Interactions for both $\mathrm{TP}$ and water temperature were driven by greater differences between treatments in 2007 compared to 2006 and 2008 (Figs. 3c and $3 \mathrm{~d}$ ). The pattern of treatment differences for both TP and temperature were consistent over the entire study, indicating no pattern of habitat response to fencing treatment implementation over three consecutive years.

Other studies involving livestock grazing impacts on sensitive amphibian species and their habitats have shown mixed results, which is potentially due to variation in life history strategies of the target species, differences in grazing management, and environment (e.g., upper montane systems vs. lower elevation, weed-invaded grasslands). In western Washington, Watson et al. (2003) reported that Oregon spotted frog individuals preferentially selected sites described as moderately grazed. The authors suggested this positive relationship was potentially due to reduced stands of invasive reed canary grass (Phalaris arundinaceae L.) in the grazed areas, resulting in greater habitat suitability for the frog. Other observational field studies have reported negative associations between amphibian abundance and cattle grazing, citing potential mechanisms such as vegetation removal and degraded water quality (Healey et al. 1997; Jansen and Healey 2003; Jofre et al. 2007). However, studies quantitatively demonstrating degraded habitat conditions in livestock-grazed systems have been conducted in intensively grazed agro-ecosystems, which experience high stocking rates (Knutson et al. 2004; Burton et al. 2009). In the system we studied, which is regulated by USFS grazing standards and guidelines, grazing intensities are relatively light to moderate. Few other field studies exist that explicitly address cattle grazing impacts on native anuran populations in extensively grazed rangeland systems. Two such studies involving livestock grazing impacts on the Columbia spotted frog (Rana luteiventris Thompson) in northeastern Oregon have shown no significant amphibian responses to grazing (Bull and Hayes 2000; Adams et al. 2009). Utilizing manipulative grazing experiments, Adams et al. (2009) reported no significant differences between grazed and ungrazed ponds in Columbia spotted frog egg mass counts, larval survival, or size at metamorphosis. Similar to our findings, they also reported that nutrient levels were low or at minimum detection limits for all ponds sampled (Adams et al. 2009).

This research focused on the potential impacts of cattle grazing on Yosemite toad meadow habitat. Field studies have shown that Yosemite toads also make use of upland terrestrial habitats for foraging and hibernation (Martin 2008; Liang 2010). Consequently, landscape activities outside meadow habitat could potentially impact toad population dynamics, yet there is little current information on the effects of landscape 
practices (e.g., road construction, logging, etc.) on Yosemite toad populations and their upland habitat.

\section{MANAGEMENT IMPLICATIONS}

The purpose of this study was to identify key habitat conditions associated with Yosemite toad occupancy of potential breeding pools and to determine if fencing to exclude cattle from meadows would affect pool habitat conditions. The USFS prompted this study because the two meadow fencing alternatives (FWM and FBA) are currently under consideration as a leading conservation strategy in Yosemite toad occupied grazing allotments. The core assumption driving this strategy was that, within this system, cattle grazing negatively impacts Yosemite toad breeding pool habitat conditions. However, the results of this study do not support the management strategy to FWMs or toad breeding areas within meadows as a means to improve upon breeding pool habitat conditions. Pool habitat conditions and toad response observed during this study do not indicate habitat impairment under standard USFS grazing management, suggesting that current grazing management guidelines are meeting these objectives. While continued examination of possible interactions between toad populations, toad habitat, and cattle grazing management should occur, additional consideration should be given to other possible factors contributing to the decline of Yosemite toad.

\section{ACKNOWLEDGMENTS}

We thank Valerie Eviner, Toby O'Geen, and two anonymous reviewers for comments on this article. We also thank the Region 5 Range Management Program and the High Sierra Ranger District, Sierra National Forest, for support on this project.

\section{LITERATURE CITED}

Adams, M. J., C. A. Pearl, B. McCreary, S. K. Galvan, S. J. Wessell, W. H. Wente, C. W. Anderson, and A. B. Kueht. 2009. Short-term effect of cattle exclosures on Columbia spotted frog (Rana luteiventris) populations and habitat in northeastern Oregon. Journal of Herpetology 43:132-138.

Allen-Diaz, B. H. 1991. Water table and plant species relationships in Sierra Nevada meadows. American Midland Naturalist 126:30-43.

Allen-Diaz, B., S. K. Mcilroy, L. M. Roche, K. W. Tate, and A. J. Lind. 2010. Determining the effects of livestock grazing on Yosemite toads (Bufo canorus) and their habitat: final report to USDA Forest Service Region 545 p. Vallejo, CA, USA: US Department of Agriculture Forest Service.

Bull, E. L., and M. P. Hayes. 2000. Livestock effects on reproduction of the Columbia spotted frog. Journal of Range Management 53:291-294.

Burton, E. C., M. J. Gray, A. C. Schmutzer, and D. L. Miller. 2009. Differential responses of postmetamorphic amphibians to cattle grazing in wetlands. Journal of Wildlife Management 73:269-277.

Davidson, C., H. B. Shaffer, and M. R. Jennings. 2002. Spatial tests of the pesticide drift, habitat destruction, UV-B, climate-change hypotheses for California amphibian declines. Conservation Biology 16:1588-1601.

Doane, T. A., and W. R. HoRWath. 2003. Spectrophotometric determination of nitrate with a single reagent. Analytical Letters 36:2713-2722.

Drost, C. A., and G. M. Fellers. 1996. Collapse of a regional frog fauna in the Yosemite area of the California Sierra Nevada, USA. Conservation Biology 10:414-425
Eaton, A. D., L. S. Clesceri, E. W. Rice, A. E. Greenberg, and M. A. H. Franson. 2005. Standard methods for the examination of water and wastewater: Centennial edition. Washington, DC, USA: American Public Health Association. 1368 p.

Fites-Kaufman, J. A., P. Rundel, N. Stephenson, and D. A. Weixelman. 2007. Montane and subalpine vegetation in the Sierra Nevada. In: M. G. Barbour, T. KeelerWolf, and A. A. Schoenherr [EDS.]. Terrestrial vegetation of California. Berkeley, CA, USA: University of California Press. p. 456-493.

Healey, M., D. Thompson, and A. Robertson. 1997. Amphibian communities associated with billabong habitats on the Murrumbidgee floodplain, Australia. Australian Journal of Ecology 22:270-278.

[ITT] Interagency Technical Team. 1996. Utilization studies and residual measurements. Denver, C0, USA: US Department of the Interior, Bureau of Land Management-National Applied Resources Science Center, Interagency Technical Reference, Report BLM/RS/ST-96/004. 164 p.

Jansen, A., and M. Healey. 2003. Frog communities and wetland condition: relationships with grazing by domestic livestock along an Australian floodplain river. Biological Conservation 109:207-219.

Jennings, M. R. 1996. Status of amphibians. In: Status of the Sierra Nevada, Sierra Nevada ecosystem project: final report to Congress. Volume 2. Davis, CA, USA: Center for Water and Wildland Resources, University of California, Davis. p. 921-944.

Jennings, M. R., And M. P. Hayes. 1994. Amphibian and reptile species of special concern in California. Final report to California Department of Fish and Game, Inland Fisheries Division. Rancho Cordova, CA, USA: California Department of Fish and Game. 255 p.

Jofre, G., C. Reading, And I. DI TAdA. 2007. Habitat selection in the Pampa de Achala toad, Bufo achalensis. Amphibia-Reptilia 28:129-138.

Jofre, M. B., AND W. H. Karasov. 1999. Direct effect of ammonia on three species of North American anuran amphibians. Environmental Toxicology and Chemistry 18:1806-1812.

Karlstrom, E. L. 1962. The toad genus Bufo in the Sierra Nevada of California. University of California Publications in Zoology 62:1-104.

Kattleman, R., and M. Embury. 1996. Riparian areas and wetlands. Davis, CA, USA: Center for Water and Wildland Resources, University of California, Davis. p. 201-267.

Knutson, M. G., W. B. Richardson, D. M. Reineke, B. R. Gray, J. R. Parmelee, and S. E. WEICK. 2004. Agricultural ponds support amphibian populations. Ecological Applications 14:669-684.

Kuhn, T. J., H. D. Safford, B. E. Jones, and K. W. Tate. 2011. Aspen (Populus tremuloides) stands and their contribution to plant diversity in a semiarid coniferous landscape. Plant Ecology 212:1451-1463.

LIANG, C. T. 2010. Habitat modeling and movements of the Yosemite toad (Anaxyrus (=Bufo) canorus) in the Sierra Nevada, California. Davis, CA, USA: University of California. $126 \mathrm{p}$.

Lind, A. J., R. Grasso, J. Nelson, K. Vincent, and C. Liang. 2011. Determining the effects of livestock grazing on Yosemite toads (Bufo canorus) and their habitat: final report addendum to USDA Forest Service Region 5. Vallejo, CA, USA: USDA Forest Service Region 5. 25 p.

MacDonald, L. H., A. Smart, and R. C. Wissmar. 1991. Monitoring guidelines to evaluate effects of forestry activities on streams in the Pacific Northwest and Alaska. Seattle, WA, USA: US Environmental Protection Agency and University of Washington. Report EPA/910/9-91-001. $166 \mathrm{p}$.

Marco, A., C. Quilchano, and A. R. Blaustein. 1999. Sensitivity to nitrate and nitrite in pond-breeding amphibians from the Pacific northwest, USA. Environmental Toxicology and Chemistry 18:2836-2839.

Martin, D. W. 2008. Decline, movement and habitat utilization of the Yosemite toad (Bufo canorus): an endangered anuran endemic to the Sierra Nevada of California. Santa Barbara, CA, USA: University of California. $406 \mathrm{p}$.

MclıroY, S. K. 2008. Identifying ecological patterns and processes in montane meadows of the Sierra Nevada range [PhD dissertation]. Berkeley, CA, USA: University of California, Berkeley. $117 \mathrm{p}$.

Morton, M. L., and M. E. Pereyra. 2010. Habitat use by Yosemite toads: life history traits and implications for conservation. Herpetological Conservation and Biology 5:388-394.

Pinhelro, J. C., and D. M. Bates. 2000. Mixed-effects models in S and S-PLUS. New York, NY, USA: Springer-Verlag. 528 p. 
Rabe-Hesketh, S., and A. Skrondal. 2008. Multilevel and longitudinal modeling using stata. College Station, TX, USA: Stata Press. 562 p.

RATLIF, R. 1985. Meadows in the Sierra Nevada of California: state of knowledge. Berkeley, CA, USA: US Department of Agriculture Forest Service General Technical Report PSW-84. 54 p.

Rouse, J. D., C. A. Bishop, AND J. StRuger. 1999. Nitrogen pollution: an assessment of its threat to amphibian survival. Environmental Health Perspectives 107:799-803.

Schmutzer, A. C., M. J. Gray, E. C. Burton, and D. L. Miller. 2008. Impacts of cattle on amphibian larvae and the aquatic environment. Freshwater Biology 53:2613-2625.

Sherman, C. K., and M. L. Morton. 1984. The toad that stays on its toes. Natural History 93:72-78.

StataCorp. 2007. Stata statistical software: release 10. College Station, TX, USA: StataCorp LP.

TAte, K. W., D. L. LAncaster, and D. F. Lile. 2007. Assessment of thermal stratification within stream pools as a mechanism to provide refugia for native trout in hot, arid rangelands. Environmental Monitoring and Assessment 124:289-300.

[USDA] US Department of Agriculture. 2001. Sierra Nevada Forest Plan Amendment: final environmental impact statement and record of decision. Vallejo, CA, USA: USDA Forest Service, Pacific Southwest Region.
[USDI] US Department OF THE INTERIOR. 2002. Endangered and threatened wildlife and plants; 12-month finding for petition to list Yosemite toad. Federal Register 67(237):75834-75843.

USDI. 2004. Endangered and threatened wildlife and plants; review of species that are candidates or proposed for listing as endangered or threatened; annual notice of findings on resubmitted petitions; annual description of progress on listing actions. Federal Register 69(86):25876-24904.

Verdouw, H., C. J. A. Vanechteld, and E. M. J. Dekkers. 1978. Ammonia determination based on indophenol formation with sodium salicylate. Water Research 12:399-402.

Watson, J. W., K. R. McAllister, and D. J. Pierce. 2003. Home ranges, movements, and habitat selection of oregon spotted frogs (Rana pretiosa). Journal of Herpetology 37:292-300.

Yu, Z. S., R. R. Northup, and R. A. Dahlgren. 1994. Determination of dissolved organic nitrogen using ersulfate oxidation and conductimetric quantification of nitrate-nitrogen. Communications in Soil Science and Plant Analysis 25:3161-3169.

Zeiner, D. C., W. F. Laudenslayer, and K. E. Mayer. 1988. California's wildlife. Volume I: amphibians and reptiles. Sacramento, CA, USA: California Department of Fish and Game. 272 p. 